Ann. Biol. anim. Bioch. Biophys., 1978, 18 (4), 871-875.

\title{
Early sex differentiation in Mugil (Liza) auratus Risso, 1810 (Teleost Mugilidae). An ultrastructural study
}

\author{
par Solange BRUSLÉ, J. BRUSLÉ
}

Laboratoire de Biologie marine, Centre Universitaire, Avenue de Perpignan, 66025 Perpignan cedex, France.

Summary. Using electron microscopy, 5 types of early germ cells (primordial germ cells or PGC, spermatogonia and primary spermatocytes, oogonia and primary oocytes) were identified by their morphological and cytological characteristics. The various stages in gonadal organization (PGC colonization, ovarian and testicular differentiation) were determined. These data have been compared to those of other fish and vertebrates and the germinal potentialities of both sexes evaluated.

\section{Introduction.}

Grey-mullet are heterosexual fish and gonochorism is the general rule. Cytological cnalysis of sex-differentiation was studied by light microscopy (Stenger, 1959 ; Leray, 1968 ; Thong, 1969 ; Cassifour, 1975), but germ-cell characteristics were not sufficiently defined at this level and no distinction could be made between primordial germ-cells, oogonia and spermatogonia.

Electron microscopy has been used to accurately describe most fish, but fine structure during early sex-differentiation was chiefly investigated on freshwater species such as Oryzias (Satoh, 1974), Poecilia (Grier, 1975) and Carassius (Yamamoto and Onozato, 1965). There are few data in the literature on the germ-cells of marine species and no information concerning grey-mullet.

We used electron microscopy for cytological identification of early germ-cells in juvenile and young golden-grey mullet Mugil (Liza) auratus.

\section{Material and methods.}

The subjects were caught by electric fishing in a mediterranean lagoon (Leucate) and the gonads were fixed in 2 p. 100 glutaraldehyde buffered with $0.12 \mathrm{M}$ sodium cacodylate and posifixed in 2 p. 100 osmium tetroxide. Ultrathin sections were stained with uranyl-acetate and lead-citrate solutions (Reynolds, 1963). 


\section{Results.}

A) Different stages of differentiating juvenile and young gonads (see fig. 1).

1. Undifferentiated gonads including scattered PGC, are observed in fish from 10 to $16.5 \mathrm{~cm}$ total body length (TL) ;

2. Ovarian differentiation is recognized (PGC, oogonia and oocytes) from $14 \mathrm{~cm}$ TL ;

3. Testicular differentiation occurs (PGC, spermatogonia and spermatocytes) from $20 \mathrm{~cm}$ TL.

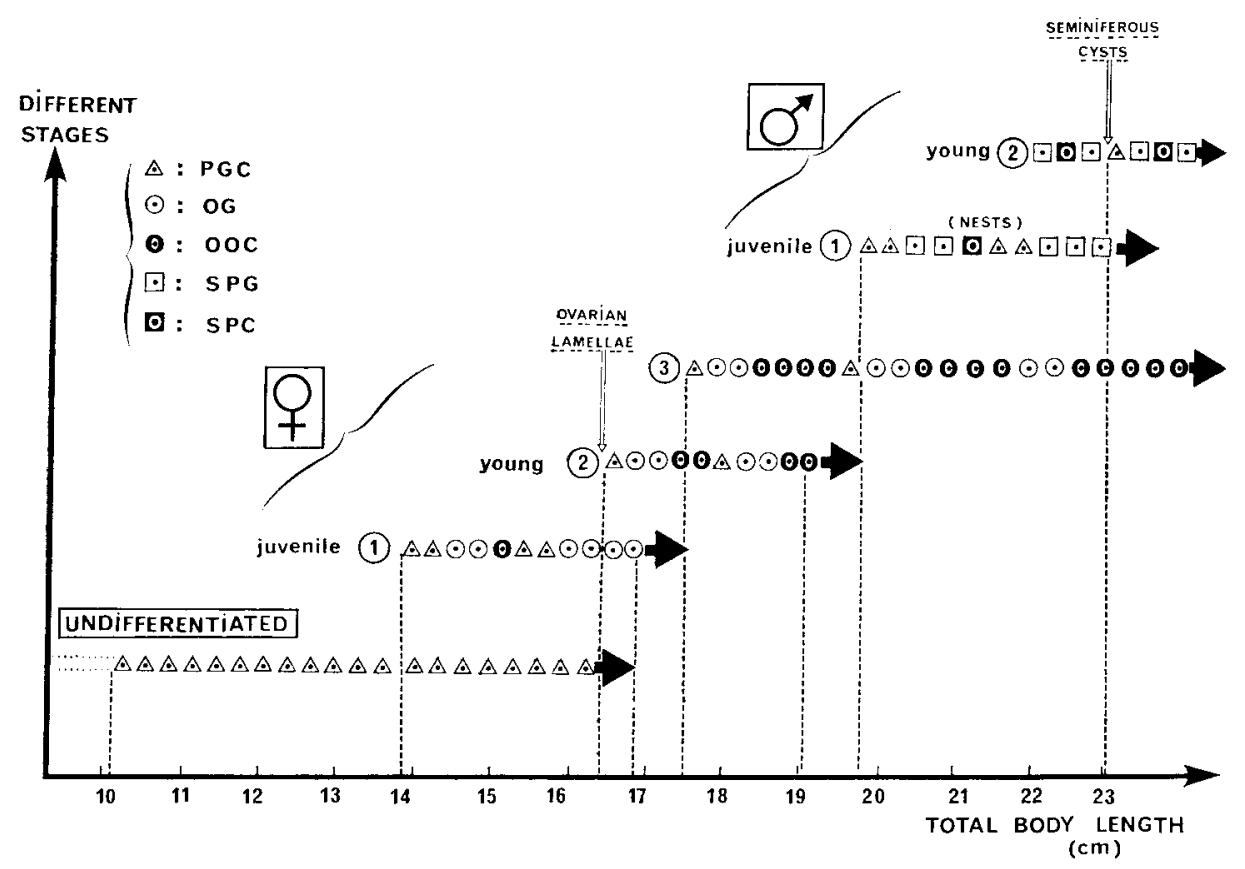

FIG. 1. - Stages of differentiating juvenile and young gonads.

B) Fine structure of germ-cells (see table 1).

Five cellular types (primordial germ-cells or PGC, spermatogonia or SPG, primary spermatocytes or SPC, oogonia or OG, primary oocytes or OOC) were recognized by their topographical, morphological and cytological characteristics.

The three earliest types of cells are evidenced by the following main features : PGC : heavy electron density, very irregular cellular and nuclear outlines, nucleolus with a large coarse granular cortex and a small fibrillar centre ;

SPG : low electron density, slightly irregular cellular and nuclear outlines, nucleus eccentrically located, nucleolus with thin granular cortex and a large fibrillar centre ; OG : low electron density, cellular outlines almost regular, nucleus ovoid or roughly spherical, almost centrally located, with regular outlines, nucleolus similar to spermatogonium. 


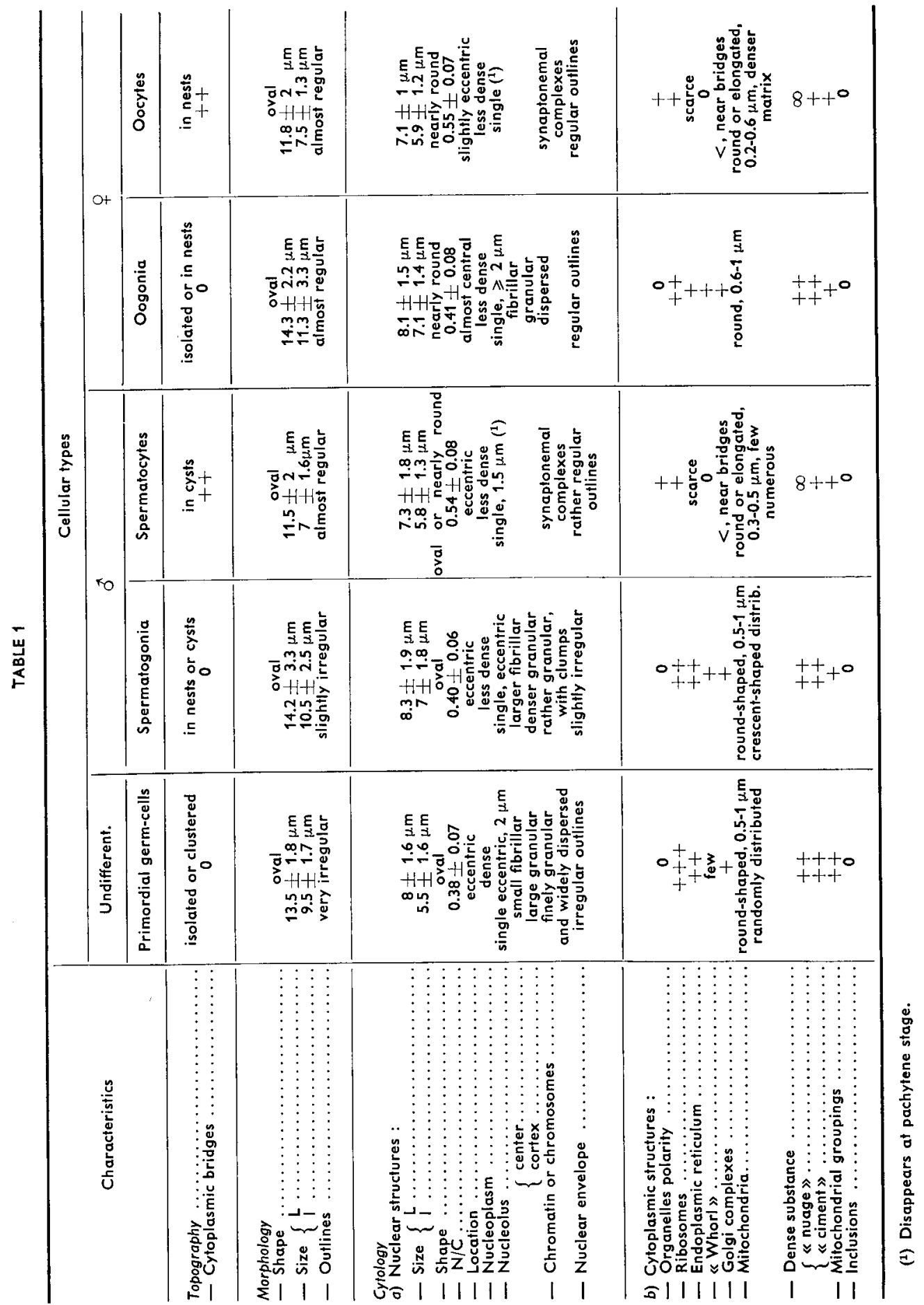




\section{Discussion and conclusion.}

Our data reveal that the colonization of somatic tissues by PGC is late in Mugil auratus. No germ-cell was evident in the gonad until a $T L$ of $9-10 \mathrm{~cm}$ was reached, when the fish were about eight months old. In other species of grey-mullet, Stenger (1959), Leray (1968), Thong (1969) asserted that the sex-colonization of gonadal primordia was earlier.

The onset of sex-differentiation in females is earlier than in males as shown in other fish ; the ovary organized from $13-14 \mathrm{~cm}$ while the testis organizes from $19-20 \mathrm{~cm}$ total length. This onset of sex-differentiation occurs at the end of the first year for the females and at the beginning of the second year for the males and therefore earlier than observed by Ezzat (1965), Cassifour (1975) and Chervinski (1976) in Mugil auratus.

Some authors (Thong, 1969 ; Cassifour, 1975 ; Remacle et al., 1977) have concluded that all early germ-cells present a similar morphological appearance. Our data reveal clear cytological differences between PGC and gonia and between oogonia and spermatogonia ; these results do not agree with the findings of Satoh (1974).

Similarity in ultrastructural features in male and female PGC suggests that these undifferentiated cells are bipotential. PGC are present in undifferentiated gonads and, in low numbers in young and even submature gonads; they constitute a permanent stock in the two sexes. It is probable that PGC are responsible for the sexual lability which characterized most fish and especially grey-mullet.

Symposium sur la Reproduction des Poissons Paimpont, France, 19-21 septembre 1977.

Résumé. Une étude des gonades juvéniles du Muge doré, effectuée en microscopie électronique, a permis d'identifier à l'aide de critères morphologiques et cytologiques cinq catégories de cellules germinales précoces (cellules germinales primordiales, spermatogonies et spermatocytes I, ovogonies et ovocytes I). II a été possible de distinguer différents stades dans l'organisation gonadique : la colonisation par les cellules germinales primordiales, la différenciation ovarienne, la différenciation testiculaire, et de juger des potentialités germinales.

\section{References}

CASSIFOUR P., 1975. Confribution à l'étude de la biologie des mugilidés des réservoirs à poissons du bassin d'Arcachon. Thèse $3^{\mathrm{e}}$ cycle, Univ. Bordeaux, $104 \mathrm{pP}$.

CHERVINSKI J., 1976. Growth of the golden-grey-mullet (Liza aurata) in saltwater ponds during 1974. Aquaculture, 7, 51-57.

EZZAT E., 1965. Contribution à l'étude de la biologie de quelques mugilidae de la région de l'éfang de Berre et du Port de Bouc. Thèse Doct. Sci., Aix Marseille, 225 pp.

GRIER H. J., 1975. Aspects of germinal cyst and sperm development in Poecilia latipinna (Teleostei : Poecilidae). J. Morph., 146, 229-250.

LERAY C., 1968. Etude histologique de l'hypophyse chez le muge et la carpe ; ses corrélations avec l'hypothalamus, la thyroïde ef les gonades. Thèse Doct. Sci. nat., Aix-Marseille, $n^{\circ} 2448,376$ pp.

REMACLE C., DELAERE P., HARRISSON F., JACQUET P., 1977. Contribution à l'étude de la différenciation des cellules germinales des poissons téléostéens. Inv. Pesq., 41, 39-65. 
REYNOLDS E. S., 1963. The use of lead citrate at high $\mathrm{pH}$ as an eleciron opaque stain in electron microscopy. J. biophys. biochem. Cytol., 17, 208-212.

SATOH N., 1974. An ultrastructural study of sex differentiation in the teleost Oryzias latipes. J. Embryol., exp. Morph., 32, 195-215.

STENGER A. H., 1959. A study of the structure and development of certain reproductive tissues of Mugil cephalus L. Zool., 44, 53-70.

THONG L. H., 1969. Contribution à l'étude de la biologie des mugilidés (poissons téléostéens) des côtes du Massif armoricain. Trav. Fac. Sci. Univ. Rennes, Océanogr. Biol., 2, 55-182.

YAMAMOTO K., ONOZATO H., 1965. Electron microscope study on the growing oocyle of the Goldfish during the first growth phase. Mem. Fac. Fish. Hokkaido Univ., 13, 79-106. 